Para enlazar con este artículo / To link to this article:

http://dx.doi.org/10.6035/MonTI.2019.ne5.8

Para citar este artículo / To cite this article:

Arza-Otana, Alicia \& Ramón Salaverría. (2019) "Playing with readers' expectations: types of predictive infographics in digital media." En: Montero Küpper, Silvia; Iván Puentes Rivera \& Montserrat Vázquez Gestal (eds.) 2019. Comunicación, Traducción e Interpretación / Communication, Translation and Interpreting. MonTI Special Issue 5, pp. 187-210.

\title{
PLAYING WITH READERS' EXPECTATIONS: TYPES OF PREDICTIVE INFOGRAPHICS IN DIGITAL MEDIA
}

\author{
Alicia ARZA-OTANO \\ aarza@alumni.unav.es \\ Universidad de Navarra \\ RAMÓN SALAVERRÍA \\ rsalaver@unav.es \\ Universidad de Navarra
}

\section{Resumen}

Los infográficos predictivos, aquellos que retan a los usuarios a hacer una estimación subjetiva en torno a un fenómeno antes de permitirles averiguar el resultado, amplían las posibilidades de los medios digitales para atraer y retener a su audiencia. Estudios recientes sugieren, además, que visualizar las propias predicciones mejora la comprensión de la información y la probabilidad de recordarla. A partir de un estudio cualitativo de infográficos interactivos, el presente artículo identifica dos tipos de gráficos predictivos presentes en los medios digitales actuales: gráficos basados en la predicción por parte de los usuarios y gráficos predictivos basados en cálculos. Analiza sus estrategias de interacción y desafío a los usuarios, describiendo modelos que pueden ser aprovechados tanto por investigadores como profesionales de la infografía periodística.

Palabras clave: infografía periodística; contenido predictivo; medios digitales; experiencia de usuario; tipologías 


\begin{abstract}
Predictive graphics, which require users to think and deduce before they can access the result, broaden possibilities for media to attract their audience. Recent research suggests that visualizing one's predictions improves recall and comprehension of data. Through a qualitative study of interactive infographics, the present article identifies two types of predictive infographics in digital media: users' prediction-based graphics and calculation-based predictive graphics. How to challenge users and interaction strategies are analyzed, describing models that could be useful for both researchers and professionals from the field.
\end{abstract}

Keywords: news graphics; predictive content; digital media; user experience; typologies

\title{
1. Theoretical Framework
}

\subsection{Attracting readers' attention: a never-ending story}

Even before the first newspapers were published, troubadours were already developing their own techniques to attract the audience to their stories. However, the rise of the penny press in the United States in the 1830s marked a milestone in how newspapers win over readers' attention.

Until then, typical daily newspapers would not distinguish editorials on politics from other news items in layout, typography or style (Schudson 1978). Also, both commercial and party press were expensive and generally sold only by annual subscription; consequently, circulation of newspapers was low. Revolution came with the penny papers, which, as the name suggests, lowered newspaper price from the average six cents to a penny. However, while circulation grew due to technological advances in printing and widespread literacy, rivalry among newspapers also intensified.

From that moment on, attracting readers' attention became crucial, since dailies were no longer sent to subscribers' homes but sold in the streets. Newsboys hawked papers in popular streets by shouting headlines and stories trying to attract clients and move buyers away from competitors (Thornton 2016). Although differences arise depending on the period and country, newspaper design has clearly evolved in order to be more visually attractive for 
readers. Research (Barnhurst \& Nerone 1991: 799) showed that between 1885 and 1995 front pages became "less dense and more orderly", displaying fewer items and more white spaces that helped enhance each item's level of importance. The need to attract readers' attention together with technological developments led to an increase in images and larger titles at the expense of reducing the number of stories portrayed on the front page.

Moreover, print newspapers' design has had, and still has, an influence on news-related websites' interface. Users have certain expectations of genres and consistency is not only expected for writing standards, but also for design (Ihlström Eriksson 2004). When the first newspapers started launching online versions of their print products, genre awareness played a key role. Web designers based their drawings on already existing conventions on the design of newspapers to help readers identify the site as news-related (Ihlström \& Lundberg 2004; Crowston \& Williams 2000).

\subsection{From penny press to clickbaiting}

Streets are no longer filled with newsboys or newspaper sellers. Their hawking rivalry has been quickly replaced by the one newspapers' profiles have in social media. Those avenues and corners are now virtual spots in users' timelines. The more followers you have, the greater the chance is that your tweets, posts or pictures are seen. And since most publications still rely on advertising, success is measured in the number of visitors a story has. But, how does media attract readers' attention? According to research, headlines are often "the primary way of getting a potential reader interested in an article" (Kuiken et al. 2017: 1311). The search for the truth has been overshadowed by the search for page views and the proliferation of clickbait headlines and stories is a clear indicator of how media tries to attract readers' attention (Kilgo \& Sinta 2016; Kuiken et al. 2017). The word clickbait is a noun or modifier which refers to "content whose main purpose is to attract attention and encourage visitors to click on a link to a particular web page" (Oxford Dictionary, n.d).

Can graphics qualify, or act, as clickbait content? Research indicates that visualizations are not only capable of integrating large amounts of data into 
the news, but also attract readers to the news and stimulate their interest in them (de Haan et al. 2017; Schroeder 2014; Gelman \& Unwin 2013). However, the term clickbait may have negative connotations associated to it. In order to properly address the connection between graphics and clickbaiting, the topic must be examined in more depth.

According to the report Lies, Damn Lies and Viral Content (Silverman 2015), in what we know as clickbait news headline and body text are often in conflict. Given that many users limit their interaction with news to reading the headline, journalists are consciously exposing their audience to misinformation. Even if a person goes beyond the default text shared in social media, there are still consequences:

This has serious implications for how news consumers process information about rumors. The overall concern, which academic research backs up, is that readers retain information from headlines more so than from body text. If readers first see a declarative headline, subsequent nuance in the article's text is unlikely to modify the original message (Silverman 2015, p. 99).

The need to make news oriented for the social media market is also related to the deliberate use of incongruity in headlines. In advertising research, the term incongruity is used to define the inclusion of information, in the form of text or image, which is perceived as dissonant or contrary to readers' expectations or previously developed schemata (Heckler \& Childers 1992). Furthermore, "incongruity in advertising may increase cognitive effort in message processing" (Lagerwerf et al. 2016: 782). Despite the possibility of enabling a better understanding, subtle misinformation can also lead to a biased interpretation of the text (Ecker et al. 2014). Research has studied whether or not incongruity in headlines is detrimental to information processing and its influence on recall, and conclusions seem to indicate that results may vary upon different news topics and that future experiments should include a wider sample of articles and users' (Lagerwerf et al. 2016; Ecker et al. 2014). However, since digital platforms can offer real-time data on audience consumption practices, analytics are more and more embedded in newsrooms daily routines (Carlson 2018; Blanchett Neheli 2018). Avoiding misinformation and attracting readers through high-quality journalism is 
therefore crucial to stay away from implementing a news selection system based on the amount of views obtained by a story without taking into account its content and clarity of understanding.

We cannot discuss clickbaiting without approaching sensationalism (Kilgo et al. 2016). The term can be understood "as a discourse strategy of 'packaging' information in news headlines in such a way that news items are presented as more interesting, extraordinary and relevant than might be the case" (Molek-Kozakowsk 2013: 173). Chen and colleagues (2015) relate this definition of sensationalism to tabloidization and they distinguish it from what are considered tabloid topics ('soft news').

Even though one could treat sensationalism as another tool media have to broaden its audience, clickbaiting does not necessarily have to be sensationalistic. Attracting readers is necessary, but journalists are expected to focus on grabbing and retaining readers' attention with high quality information. Questioning their prejudices and principles, showing them striking graphics or asking them to interact and predict information are some strategies for a "good clickbaiting". In addition, the readers' cognitive interest in a specific story may increase as a result of their need to draw hypothetical predictions (Campion et al. 2009). Therefore, the use of graphics to challenge the audience's preconceptions may be considered as a high-quality resource for better journalism practices and higher readership rates.

\subsection{Challenging readers' preconceptions}

Internet, technological advances and social media have unquestionably changed the way citizens interact and search for information. Even though there are still countries where freedom of speech and access to news are limited, internet has broadened the horizon of knowledge. On the one hand, one could think that today's situation is the best possible one for people to educate themselves on different topics. On the other hand, internet has also made it possible for unreliable sources to deliver unchecked stories and rumors.

Online-only publications rely largely on clicks and shares to equal revenue (Kilgo \& Sinta 2016). The overabundance of sources and the need to publish breaking-news to compete for clicks has affected the way media reports about 
rumors and unverified claims. The Emergent database (http://www.emergent. info/), described in the website as "a real-time rumor tracker", was created as part of a research project from the Tow Center for Digital Journalism at Columbia University. Silverman's report (2015) shows how media informed about the unverified claim that eleven commercial aircraft went missing from the Tripoli airport and that Western intelligence was worried they might be used for terrorist attacks. The first person to report on the issue was Bill Gertz of The Washington Free Beacon in September 2, 2014. However, different media platforms spread the information and shared as if it was true, even though there were no identified sources. This example shows "the low bar required for news websites to follow-on an alarming, yet thinly sourced claim from another news outlet" (Silverman 2015: 94).

Moreover, research shows people consume media sharing their political predispositions, resulting in what has been called selective exposure (Stroud 2008). In an environment of overabundance of information, this statement may seem as an opportunity for media to strategically seek for their potential audience. However, it also challenges journalists to win over readers' preconceptions on certain topics.

The continuous development of search engines and website algorithms has made it possible for media to offer personalized content to users. However, this has led to worries about filter bubbles and the aforementioned selective exposure. Researchers have claimed that this individualized content could have an effect on democratic discourse and people's open-mindedness since the diversity of media people are exposed to would be limited (Pariser 2011; Zuiderveen Borgesius et al. 2016). However, recent findings suggest that, in the context of online news, concerns about algorithmic filter bubbles may be exaggerated (Haim et al. 2017). The consequences of self-selection, choosing to follow or unfollow certain news-related users, should not be underestimated either. According to data presented in the Reuters Institute Digital News Report 2017, 36 percent of respondents claimed to have added a user for news, and around 20 percent said they had blocked someone because of news they posted (Fletcher 2017: 42-43). 


\subsection{The role of infographics}

The term infographics has an unclear origin and it is not used by all professionals in the field, some of whom prefer to refer to their work as graphics. However, news graphics are defined as "visuals that contain useful, relevant, and newsworthy content, and that are designed based on journalistic values and principles" (Cairo, 2017, p. 22). Some common individual news graphs are graphs, charts, schemes or locator maps. However, these can be used together on a larger graphic. As Cairo states: "An infographic is a combination of several individual graphics which, along with copy that ties them together and provides context, offers readers a complete overview of a story, often - but not always - structuring the information in a sequential manner" (Cairo 2017: 25-28).

However, with the development of internet and computer software, graphics can now be interactive and not only static, and the term data visualization has gained popularity. In research, different definitions have been given of the term "data visualization", with meanings ranging from a general synonym of infographics to specific, interactive pieces. According to Brigham (2016: 215), "data visualization is the graphical or pictorial representation of data or information in a clear and effective manner", and Cairo (2017: 30) describes it as a graphic "intended to enable exploration, rather than a unidirectional conveyance of information from an emitter (the journalist) and a receiver (the reader)". Yael de Haan et al. (2017: 1294) choose to use the term in their study to refer to "a journalistic story that uses data, and that is told both in text and visuals". And they continue to clarify that, from their perspective, "the term 'data' does not only refer to bif or quantitative data, but can also include qualitative data".

Additionally, other terms have been used to describe this way of telling. Burmester et al. (2010) state the following expressions having been used: interactive graphics, explanation graphics, multimedia features, animated graphics, and interactive narratives. Nevertheless, in their work they define interactive information graphics as "a hybrid presentation of different modalities: text, photos, audios, videos, charts, maps, graphs, illustrations" which are combined and where "the interplay of these is more than the sum of 
the parts" (361). Also, they define interactivity and hypertextuality as main characteristics of interactive information graphics and point out that each information graphic focuses on one topic or story (Burmester et al. 2010).

Infographics as a journalistic genre arose during the 1980's and early 1990s, when newspapers started creating their own departments devoted to this task. A professional identity, that of graphic artists or infographists, was generated from these groups of people who found support in international conferences and competitions such as those from the Society for News Design or, specifically, Malofiej International World Summit and Awards. Nowadays some large media companies still have their graphics team, but most newspapers have teams that not only produce graphics but also videos, illustrations, etc. (Cairo 2017: 33).

Infographics are oriented to interactivity so it could be considered a genre especially suitable for carrying out research on predictability of users' behavior. In addition, it is a recurring genre when it comes to explaining large volumes of information and to explain abstract concepts which are hard to understand. These reinforce the idea that it is a genre for high-quality journalism and that, moreover, it is very appropriate for carrying out research on users' behavior.

Studies on visualization comprehension show the importance of prior knowledge and internal representation of information - mental models of what is known. Specifically, research suggests that users' interactions with their internal representation of the data are critical to the interpretation process and also improve recall of data values. Critical thinking can benefit from expressing internal representations which can also "prompt changes to existing beliefs to account for new information" (Kim et al. 2017: 1375). According to the aforementioned research, "most visualizations do not provide ways for users to explicitly incorporate their internal representations" and You Draw It from The New York Times is a rare exception (Kim et al. 2017: 1375).

Predictive graphics, those which require users to prompt their prior knowledge, can be an excellent way to capture readers' attention. "A person's curiosity is piqued when she perceives an information gap between her knowledge and the information she is interested in" (Kim et al. 2017: 
1376) and asking people to predict could be a way to make this gap explicit. Finally, research suggests that audience interacts more with articles containing graphics than with those without them (Tian 2015), proving that information graphics promote interactions between media and its audience.

\section{Methodology}

The present study follows a descriptive methodology, based on content analysis. The objective is not only to provide a typology of predictive graphics, but also to evaluate to what extent they are considered as good infographics by practitioners.

As remarked above, infographists or graphic artists have built their professional identity around competitions and international summits. Without any doubt, the Malofiej awards are the most prestigious infographic recognitions to aim for. Every year, the so-called Pulitzer awards of information graphics gather together the greatest professionals from all over the world. Journalists and experts from renowned organizations and media such as The New York Times, National Geographic, The Washington Post, ProPublica or The Guardian constitute the jury. For three days these professionals review all entries submitted to competition in online and printed categories and award bronze, silver and gold medals to those pieces of work considered as the best examples of what an infographic should be.

In order to guarantee a high quality sample only award winning pieces will be revised. Since Malofiej is the only competition exclusively on infographics - other design contests have graphics categories - the present article will focus on reviewing the Malofiej prizes from 2013 to 2017 (editions $21^{\text {st }}$ to $25^{\text {th }}$ ). The contest evaluates both printed and online graphics; however, only the digital entries have been considered as part of the sample.

Even though we cannot assume that every predictive graphic done in newsrooms is being submitted to competition, Malofiej is well known among infographists and, in view of the inability to track every single graphic published worldwide during five years, the sample provided represents the best possible option to review. 
Research was carried out as follows: Firstly, graphics that make up the sample were located by reviewing the online categories in Malofiej books from editions $21^{\text {st }}$ to $25^{\text {th }}$. Once the total sample was obtained, every graphic was evaluated by looking for those clearly involving readers' preconceptions, which would require user's input as a prediction or to generate a prediction.

\section{Findings}

During Malofiej's $21^{\text {st }}$ edition in 2013, 1,191 entries were submitted to competition with 322 in the online categories. The jury awarded 55 medals for online graphics but none was given to predictive graphics; there is no record of any piece of work of this type being presented. The following year, during Malofiej's 22 ${ }^{\text {nd }}$ edition (2014), 356 graphics entered the online categories from a total of 1,290 entries submitted to competition. Juries gave 71 online medals including two graphics which involved readers' preconceptions or demanded user input for prediction.

The first such graphic awarded a medal is called How Y'all, Youse and You Guys Talk and was submitted by The New York Times. The piece was given a silver medal and also the Miguel Urabayen Award for the Best Online Map. The interactive asks users certain questions about the way they speak in order to locate their origin on a map, producing personal dialect maps. In other words, by asking readers to introduce certain linguistic information they may not be aware of, the graphic predicts a map showing where each person possibly comes from. 
Figure 1. How Y'all, Youse and You Guys Talk (The New York Times)

\section{How Y'all, Youse and You Guys Talk \\ By JOSH KATZ and WILSON ANDREWS DEC. 21, 2013 \\ What does the way you speak say about where you're from? Answer \\ all the questions below to see your personal dialect map.}

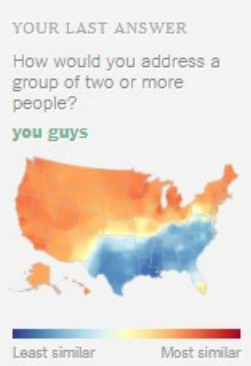

QUESTION 2 OF 25

What is the distinction between dinner and supper?

supper is an evening meal; dinner is eaten earlier

supper is an evening meal; dinner is the main meal

dinner takes place in a more formal setting than supper

there is no distinction; they both have the same meaning

I don't use the word supper

I don't use the word dinner

other

Published on December 21, 2013. Source: https://www.nytimes.com/interactive/2014/ upshot/dialect-quiz-map.html

The second graphic receiving an award was also by The New York Times and is called Housing's Rise and Fall in 20 cities. In this case, the gold-winning interactive piece invites users to introduce information about when and where a house was bought in order to provide data on how much it will be worth today. The infographic tests preconceptions on how the real estate market has developed.

In Malofiej 23 (2015), online entries kept growing in number - 458 out of 1,266 submitted. Professionals decided to give 49 medals, three of them to predictive-related graphics. Published by Los Angeles Times, L.A.'s Eastside: Where do you draw the line? earned a silver medal for asking readers to submit their maps and contribute to the debate. The resulting graphic shows where 
people delimit L.A.'s Eastside and also allows users to send definitions for their maps available for everyone to check.

Figures 2 and 3. L.A.'s Eastside: Where do you draw the line? (Los Angeles Times)

\section{L.A.'s Eastside: Where do you draw the line?}

66

Anything East of East Hollywood and not downtown
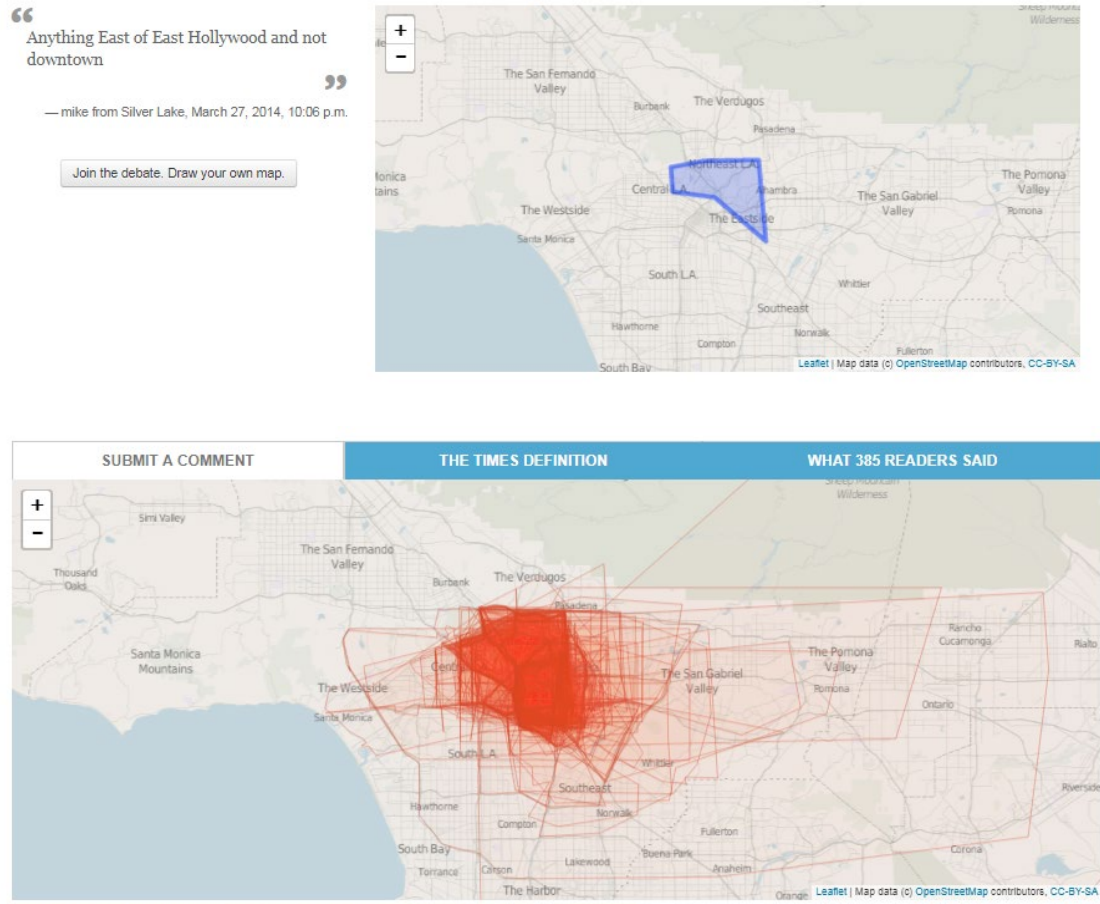

Alert: Tablet and phone users can leave a comment, but to submit a custom map you must use a laptop or desktop computer.

Published on February 16, 2014. Source: http://maps.latimes.com/debates/eastside 
The other two medal-winning graphics were from The New York Times and were entitled How birth year influences political views and Where we came from and where we went. These infographics do not ask the audience to prompt what the result may be, but offer the possibility to navigate through information they have preconceived ideas about.

Online entries reached 729 out of 1,288 in Malofiej's $24^{\text {th }}$ edition (2016), when only one of the 58 medals was given to a predictive graphic. Apart from the aforementioned medal, another award worth mentioning was given in 2016. The entry Who's winning? Find out how your income compares with every other generation, from the The Guardian (UK) won a silver medal, although it should be noted that this was not a predictive graphic. The piece of work is another example of how to use large amounts of data to make users explore their preconceived ideas.

However, it was The New York Times' interactive You Draw It: How Family Income Predicts Children's College Chances that won not only a medal, but also the Best of Show Award, the most important recognition given every year at Malofiej. The jury rewarded its innovative format which asks users to predict how much family income influences percentage of children attending college. Once the reader has introduced their guess, the graphic shows the correct answer and also how others have performed. 
Figures 4, 5 and 6: You draw it: How Family Income Predicts Children's College Chances (The New York Times)

\section{Draw your line on the chart below}

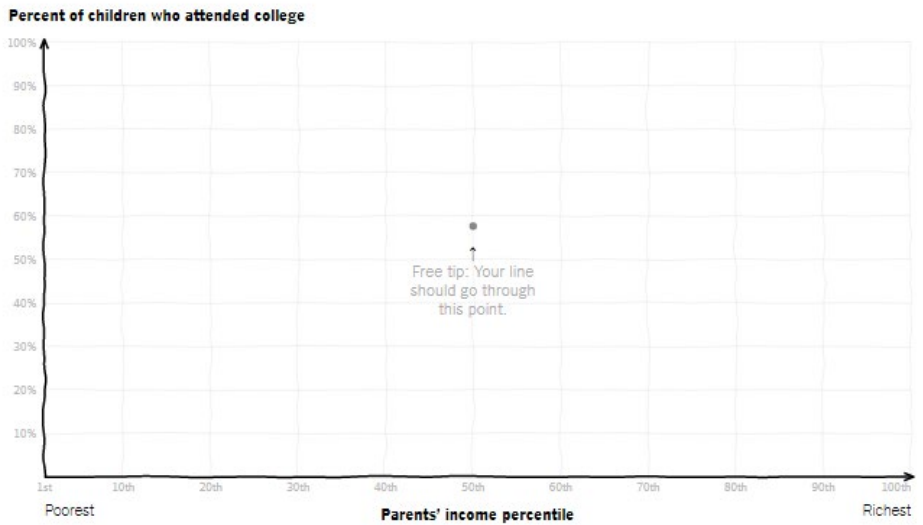

\section{Well done!}

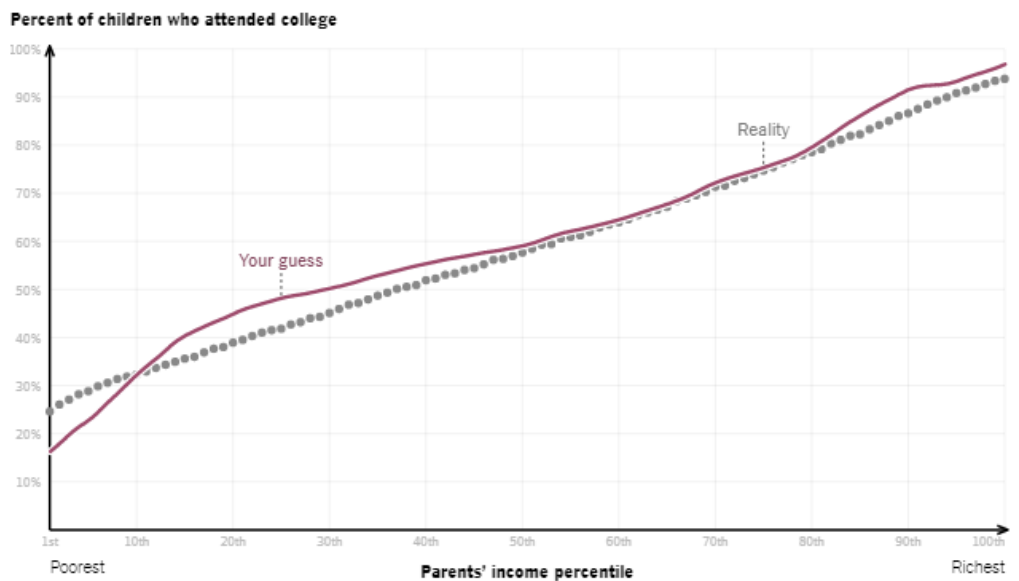




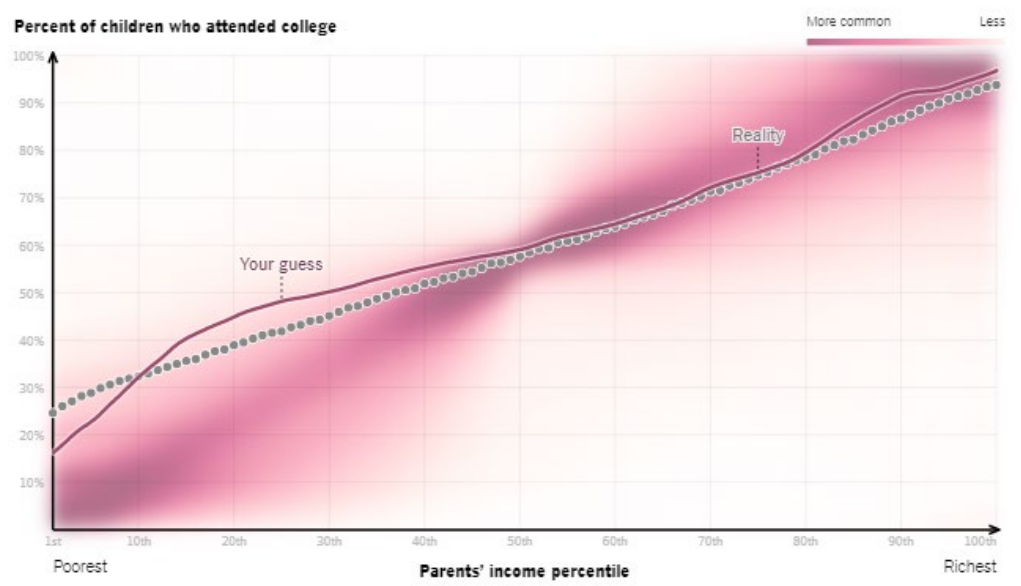

Published on May 28, 2015. Source: https://www.nytimes.com/interactive/2015/05/28/ upshot/you-draw-it-how-family-income-affects-childrens-college-chances.html

Once users have introduced their prediction, The New York Times offers its readers an explanation for why they are asked to guess:

Now let's get to the reason for this exercise: Reality forms a remarkably straight line. We asked you to take the trouble to draw a line because we think doing so makes you think carefully about the relationship, which, in turn, makes the realization that it's a line all the more astonishing (NYTimes. com, May 28, 2015).

Moreover, in Malofiej's 25 ${ }^{\text {th }}$ edition (2017) three graphics relevant to the present research won medals. In the latest edition, 1,334 entries were submitted to competition and 584 out of those were sent to the online categories, in which 85 medals were given. Here's $\$ 100$. Can you win $\$ 1.5$ billion at Powerball?, from Los Angeles Times, gave users the possibility to understand how lottery works without risking their money. This Chart Shows Who Marries CEOs, Doctors, Chefs and Janitors, by Bloomberg News, enables readers to test whether or not their beliefs on who marries whom are accurate. 
Table 1. Malofiej summary of entries, medals and predictive graphics

\begin{tabular}{|c|c|c|c|c|}
\hline Edition & $\begin{array}{c}\text { Entries } \\
\text { submitted to } \\
\text { competition }\end{array}$ & $\begin{array}{c}\text { Online } \\
\text { entries }\end{array}$ & $\begin{array}{c}\text { Online medals } \\
\text { awarded }\end{array}$ & $\begin{array}{c}\text { Awarded } \\
\text { predictive } \\
\text { graphics }\end{array}$ \\
\hline Malofiej 21 & 1,191 & 322 & 55 & 0 \\
\hline Malofiej 22 & 1,290 & 356 & 71 & 2 \\
\hline Malofiej 23 & 1,266 & 458 & 49 & 3 \\
\hline Malofiej 24 & 1,388 & 729 & 58 & 2 \\
\hline Malofiej 25 & 1,334 & 584 & 85 & 2 \\
\hline
\end{tabular}

Source: Malofiej books and Malofiej website.

To sum up, even though in the last five Malofiej editions only three awarded graphics were clearly predictive, another six relate to users' preconceived ideas and expectations.

\section{Discussion}

Although research claimed You Draw It (...) graphic from The New York Times was a rare exception (Kim et al. 2017), our review has noticed an increase in predictive graphics. Also, since the aforementioned graphic won the Best of Show, we searched the newspaper's website and found they have replicated the model and produced at least two more infographics based on predictions: You draw it: Just how bad is the drug overdose epidemic? and You Draw It: What Got Better or Worse During Obama's Presidency. These journalistic interactives are good examples of how to attract readers and have them face their preconceived ideas. According to what research has shown, even if there is a selective exposure or a filter bubble, professionals still have ways to approach users.

In social media's current situation of overabundance of information, attracting readers' attention could be done with high-quality journalism. Research reviewed in this article suggests that graphics represent a good opportunity to engage with users. Also, the benefits of predicting information have not only been tested by researchers but also supported by professionals in the most important infographics awards. Despite the limited bibliography on the cognitive efficiency of graphics and the emerging state of predictive graphics, some issues can be addressed. 
Based on the observed cases, and despite their limited number, two types of predictive graphics can be identified in digital news media:

1. Users' prediction-based graphics. These graphics pose a question or a problem to the users, who are challenged to guess the correct answer or to predict the result, according to their knowledge on the subject. Therefore, the predictive component of these graphics relies mainly on the users' minds.

2. Calculation-based predictive graphics: These graphics invite the users to contribute some data and, based on the information collected, calculate a result and build a prediction. These graphics do not challenge the users to find out a correct answer, but just ask them to contribute their data to produce an analysis. Here, the predictive component relies on the calculation made by the graphic, which provides predictions for future users based on the answers given by the users in the past.

Both types of predictive graphics are designed to make the audience think about different possible scenarios and to take time to realize and explain their knowledge gaps. On the basis of graphics found in Malofiej's editions $21^{\text {st }}$ to $25^{\text {th }}$, it seems that predictive graphics are still not very frequent. However, both researchers and professionals from media all over the world appear to agree on the high-quality of these pieces of work. Lastly, the incipient development of predictive graphics in news media makes it difficult to define a more detailed typology. Further academic research and tracking future predictive stories appear to be necessary to develop and clarify this way of telling.

Although, as remarked above, future research is required to broaden knowledge on predictive graphics, apparently both academics and professionals agree on the high-quality and effectiveness of asking users to speculate on what the result would be. Naturally, the present research also presents some limitations such as the scarce number of predictive graphics and the impossibility to track every graphic published worldwide.

Despite having resolved the tracking limitation by selecting the best possible sample, future research could be carried out by taking into account a larger number of graphics. In addition, a more in-depth analysis of every predictive graphic to increase the understanding of the typology is suggested. 
Future studies should carry out individual research of each graphic through eye-tracking technology, user surveys and other user-testing methods. Conclusions from our research may help professionals achieve better engagement with their audience and suggest the possibility of great benefits arising from knowledge transfer between academia and media industry.

Expectations have a lot to do with clickbaiting and attracting the audience in competitive social media timelines, and predictive graphics appear to be a great tool to challenge overabundance of information and a possible selective exposure. Playing with readers' expectations could be summed up as being able to achieve the difficult goal of maintaining their attention until the very last sentence, or, in this case, the very last graphic.

\section{References}

Barnhurst, Kevin G. \& John C. Nerone. (1991) "Design trends in US front pages, 1885-1985." Journalism Quarterly 68:4, pp. 796-804. https://doi. org/10.1177/107769909106800420

BlanCHETt NeHELI, Nicole. (2018) "News by Numbers. The evolution of analytics in journalism." Digital Journalism 6:8, pp. 1041-1051. https://doi.org/10.108 0/21670811.2018.1504626

Bloomberg News. (2016) "This Chart Shows Who Marries CEOs, Doctors, Chefs and Janitors." Electronic version: <https://www.bloomberg.com/ graphics/2016-who-marries-whom/>

BRIGHAM, Tara. (2016) "Feast for the Eyes: An Introduction to Data Visualization." Medical Reference Services Quarterly 35:2, pp. 215-223. DOI: 10.1080/02763869.2016.1152146

Burmester, Michael; Marcus MAst; Ralph Tille \& Wibke Weber. (2010) "How

Users Perceive and Use Interactive Information Graphics: An Exploratory Study." 14th International Conference on Information Visualisation, IV 2010, 26-29 July 2010, London, UK. https://doi.org/10.1109/iv.2010.57

CAIRO, Alberto. (2017) Nerd Journalism: How data and digital technology transformed news graphics. Doctoral Thesis, Universitat Oberta de Catalunya. Electronic version: <https://www.dropbox.com/s/umr3r11v8dc088x/nerdJournalismDISSERTATION.pdf?dl=0>

CARLSOn, Matt. (2018) "Confronting Measurable Journalism." Digital Journalism 6:4, pp. 406-417. https://doi.org/10.1080/21670811.2018.1445003 
Crowston, Kevin \& Marie WiLliams. (2000) "Reproduced and emergent genres of communication on the World-Wide Web." The Information Society 16:3, pp. 201-215. http://doi.org/10.1080/01972240050133652

CHEN, Yimin; Nadia CONROY \& Victoria RuBIN. (2015) "Misleading online content: Recognizing clickbait as false news." In: Proceedings of the 2015 ACM on Workshop on Multimodal Deception Detection, pp. 15-19. http://www.doi. org/10.1145/2823465.2823467

De HaAn, Yael; Sanne Kruikemeier; Sophie LeCheler; Gerard Smit \& Renee VAN DER NAT. (2017) "When does an infographic say more than a thousand words? Audience evaluations of news visualizations." Journalism Studies, pp. 1-20. http://www.doi.org/10.1080/1461670X.2016.1267592

ECKer, Ullrich; Stephan Lewandowsky; Ee Pin Chang \& Rekha Pillai. (2014) "The effects of subtle misinformation in news headlines." Journal of Experimental Psychology: Applied 20:4, pp. 323-335. http://www.doi. org/10.1037/xap0000028

FLETCHER, Richard. (2017) Social media and incidental exposure, Reuters Institute Digital News Report 2017, Reuters Institute. Electronic version: <https:// reutersinstitute.politics.ox.ac.uk/sites/default/files/Digital\%20News $\% 20$ Report\%202017\%20web_0.pdf>

GELMAN, Andrew \& Antony Unwin. (2013) "Infovis and statistical graphics: different goals, different looks." Journal of Computational and Graphical Statistics 22:1, pp. 2-28. http://www.doi.org/10.1080/10618600.2012.761137

HAIM, Mario; Andreas GRAEFE \& Hans-Bernd Brosius. (2017) "Burst of the filter bubble? Effects of personalization on the diversity of Google News." Digital Journalism, pp. 1-14. https://doi.org/10.1080/21670811.2017.1338145

HeCKLER, Susan E. \& Terry L. CHILDERS. (1992) "The Role of Expectancy and Relevancy in Memory for Verbal and Visual Information: What is Incongruency?" Journal of Consumer Research 18:4, pp. 475-492. http://www. doi.org/10.1086/209275

Holsanova, Jana; Nils HolmberG \& Kenneth HolmQvist. (2009) "Reading information graphics: The role of spatial contiguity and dual attentional guidance." Applied Cognitive Psychology 23, pp. 1215-1226. http://www.doi. org/10.1002/acp.1525

IHLSTRÖM ERIKSSON, Carina. (2004) The evolution of a new (s) genre. Doctoral dissertation. Gothenburg: Department of Informatics, Gothenburg 
University. Electronic version: <http://www.diva-portal.org/smash/record. jsf?pid=diva2\%3A237485\&dswid $=2577>$

IHLSTRÖM, Carina, \& Jonas LUNDBERG. (2004) "A genre perspective on online newspaper front page design." Journal of Web Engineering 3, pp. 50-74.

KILGO, Danielle K. \& Vinicio SinTA. (2016) "Six things you didn't know about headline writing: Sensational form in viral news of traditional and digitally native news organizations." The Official Journal of the International Symposium of Online Journalism 6:1, pp. 111-130. Electronic version: <https://isojjournal. wordpress.com/2016/04/14/six-things-you-didnt-know-about-headline-writing-sensational-form-in-viral-news-of-traditional-and-digitally-native-newsorganizations/>

Kilgo, Danielle K.; Summer Harlow; Víctor García-Perdomo \& Ramón SALAVERRíA. (2016) "A new sensation? An international exploration of sensationalism and social media recommendations in online news publications." Journalism, 1464884916683549. https://doi.org/10.1177/1464884916683549

KIM, Yea-Seul; Katharina REINECKE \& Jessica Hullman. (2017) "Explaining the gap: Visualizing one's predictions improves recall and comprehension of data." In: Proceedings of the 2017 CHI Conference on Human Factors in Computing Systems, pp. 1375-1386. https://doi.org/10.1145/3025453.3025592

Kuiken, Jeffrey; Anne Schuth; Martijn SPitTers \& Maarten MarX. (2017) "Effective headlines of newspaper articles in a digital environment." Digital Journalism 5:10, pp. 1300-1314. https://doi.org/10.1080/21670811.2017.12 79978

Los ANGElES Times. (2014) "L.A.'s Eastside: Where do you draw the line?" Electronic version: <http://maps.latimes.com/debates/eastside/>

LOS ANGELES Times. (2016) "Here's \$100. Can you win $\$ 1.5$ billion at Powerball?" Electronic version: <http://graphics.latimes.com/powerball-simulator/>

LAGERWERF, Luuk; Carly Timmerman \& Anique Bosschaert. (2016) "Incongruity in News Headings." Journalism Practice 10:6, pp. 782-804. http://www.doi. org/10.1080/17512786.2015.1063446

MoleK-KozAKOWSK, Katarzyna. (2013) "Towards a pragma-linguistic framework for the study of sensationalism in news headlines." Discourse $E$ Communication 7:2, pp. 173-197. https://doi.org/10.1177/1750481312471668

OXFORD Dictionary. (n.d) Definition of clickbait in English. Electronic version: $<$ https://en.oxforddictionaries.com/definition/clickbait> 
PARISER, Eli. (2011) The filter bubble: What the Internet is hiding from you. New York: Penguin.

SCHROEDER, Roland. (2004) "Interactive Info Graphics in Europe--added value to online mass media: a preliminary survey." Journalism Studies 5:4, pp. 563570. https://doi.org/10.1080/14616700412331296473

SCHUDSON, Michael. (1981) Discovering the news: A social history of American newspapers. New York: Basic Books.

Silverman, Craig. (2015) "Lies, Damn Lies and Viral Content: How News Websites Spread (and Debunk) Online Rumors, Unverified Claims and Misinformation.", Tow Center for Digital Journalism, Columbia University. https://doi. org/10.7916/D8Q81RHH

STROUD, Natalie Jomini. (2008) "Media use and political predispositions: Revisiting the concept of selective exposure." Political Behavior 30:3, pp. 341-366. http://www.doi.org/10.1007/s11109-007-9050-9

THE GUARDIAN. (2016) Who's winning? Find out how your income compares with every other generation. Electronic version: $<$ https://www.theguardian.com/world/ng-interactive/2016/mar/07/whos-winning-find-out-how-your-income-compares-with-every-other-generation>

THE NeW York Times. (2013) "Y'all, Youse and You Guys Talk." Electronic version: <https://www.nytimes.com/interactive/2014/upshot/dialect-quiz-map. html>

THE NeW York Times. (2014) "Where we came from and Where we went, State by state." Electronic version: <https://www.nytimes.com/interactive/2014/08/13/ upshot/where-people-in-each-state-were-born.html>

THE New YoRk Times. (2017) "You Draw It: What Got Better or Worse During Obama's Presidency." Electronic version: <https://www.nytimes.com/interactive/2017/01/15/us/politics/you-draw-obama-legacy.html>

THE New York Times. (2014) "Housing's Rise and Fall in 20 cities." Electronic version: <https://www.nytimes.com/interactive/2014/01/23/business/caseshiller-slider.html>

THE NEW YORK TIMES. (2014) "How birth year influences political views." Electronic version: <https://www.nytimes.com/interactive/2014/07/08/ upshot/how-the-year-you-were-born-influences-your-politics.html>

The New York Times. (2015) "You draw it: How Family Income Predicts Children's College Chances." Electronic version: <https://www.nytimes.com/ 
interactive/2015/05/28/upshot/you-draw-it-how-family-income-affects-childrens-college-chances.html>

THE New York Times. (2017) "You draw it: Just how bad is the drug overdose epidemic?" Electronic version: <https://www.nytimes.com/interactive/2017/04/14/upshot/drug-overdose-epidemic-you-draw-it.html>

THORNTON, Leslie-Jean. (2016) "The road to 'reader-friendly': US newspapers and readership in the late twentieth century." Cogent Social Sciences 2:1. https:// doi.org/10.1080/23311886.2016.1189055

TIAN, Quing. (2015). How information graphics promote interactions between the media and audiences. Thesis, Master of Arts. University of Missouri-Columbia. Electronic version: <https://mospace.umsystem.edu/xmlui/bitstream/ handle/10355/48624/research.pdf>

ZuiderVEen Borgesius, Frederik J; Damian Trilling; Judith Möller; Balazs Bodó; Claes DE VREESE \& Natali Helberger. (2016) "Should we worry about filter bubbles?” Internet Policy Review 5:1. https://doi.org/10.14763/2016.1.401

\section{BIONOTES / BIONOTAS}

Alicia ARZA-OtAno (Pamplona, Spain) graduated in Journalism at the University of Navarra. During her second year at university she became a student staff member of the Spanish Chapter of the Society for News Design (SND-E). She has been involved in the organization and development of two NH Journalistic Design Awards and Summits, and five Malofiej International Awards, Workshops and Infographics World Summits. She also worked as a summer intern at the Design Department in El Correo, Bilbao's leading newspaper. Half Spanish and half American, she owns a Masters' Degree in Teaching English as a Foreign Language, an area where she has wide experience. While earning her Masters' Degree she worked part time in Palliative Care Research and Communication. She describes herself as a "Design Lover and data freak" and she is currently pursuing her $\mathrm{PhD}$ in Communication, focusing on the Cognitive Efficiency of Graphics, and teaching at her Alma Mater.

RAMÓn SAlaVerría (Burgos, Spain) is Associate Dean of Research at the School of Communication of the University of Navarra, where he is also 
the Assistant Director of the Center for Internet Studies and Digital Life. Associate Professor of Journalism, he has taught online journalism skills for nearly twenty years. His research focuses on media convergence, online news storytelling and new media trends, topics on which he has published many research papers, chapters and books. His most recent title, "Ciberperiodismo en Iberoamérica" (2016), offers a detailed analysis of the evolution of digital media in 22 countries in Latin America, Spain and Portugal. Salaverría has steadily led several national and international research projects about online journalism, focusing on media convergence, online newswriting and new media trends. He was Chair of the Journalism Studies Section at the European Communication Research and Education Association (ECREA) during the term 2010-2012. In addition, he was appointed by the United Nations Alliance of Civilizations (UNAOC) to be member of Global Experts, a directory of roughly 400 world-class specialists.

Alicia ArZA-Otano (Pamplona, España) es graduada en Periodismo por la Universidad de Navarra. Durante su segundo año de carrera se unió al equipo de estudiantes del Capítulo Español de la Society for News Design (SND-E). Ha participado en la organización y desarrollo de dos ediciones de los premios y congresos ÑH sobre diseño periodístico, así como en cinco ediciones de los Premios Internacionales Malofiej y en sus cumbres mundiales de infografía. También trabajó como becaria en la sección de Diseño de El Correo de Bilbao. Mitad española, mitad estadounidense, posee un Máster de Enseñanza de Inglés como lengua extranjera, área en la que posee amplia experiencia. Mientras cursaba dicho máster trabajó a media jornada en la investigación y comunicación pública de cuidados paliativos. Se describe a sí misma como "Amante del diseño y friki de los datos". Actualmente está realizando su tesis doctoral acerca de la eficiencia cognitiva de los gráficos en la Facultad de Comunicación de la Universidad de Navarra donde también imparte clases.

RAMÓN SALAVERRía (Burgos, España) es vicedecano de Investigación de la Facultad de Comunicación de la Universidad de Navarra, donde además es subdirector del Center for Internet Studies and Digital Life. Profesor Titular de Periodismo, ha impartido clases sobre periodismo online durante cerca de veinte años. Su investigación en ciberperiodismo y medios digitales se centra en la convergencia de los medios, modos de contar y tendencias informativas, 
temas sobre los que ha publicado numerosos artículos, capítulos y libros. Su libro más reciente, Ciberperiodismo en Iberoamérica (2016), es un detallado análisis de la evolución de los medios digitales en los 22 países de América Latina, España y Portugal. Salaverría ha dirigido, de manera incesante, proyectos nacionales e internacionales sobre periodismo online, centrándose en la convergencia mediática, la escritura para medios digitales y en las tendencias periodísticas. Ha sido chair de la Journalism Studies Section de ECREA (European Communication Research and Education Association) y fue seleccionado por la Organización de las Naciones Unidas como parte de Global Experts, su directorio de aproximadamente 400 especialistas de primer orden. 